socio-economic problems, energy policy, safety, social repercussions, influence on climate and biomedical problems. The discussion on each subject can be held in one place only, but written contributions are also accepted.

Each meeting is prepared by a subgroup of five or six experts, including natural scientists, sociologists and economists. West Germans, Swiss and even an eminent Bulgarian are among the members. In preparatory meetings, each group tries to reach factual agreement as far as possible but does not hide internal divergences when it faces the meeting. Disagreements are bound to be pronounced as in every case both friends and foes of nuclear energy have been appointed to the groups. They do not include, however, members of the nuclear establishment, notably employees of the companies that build or plan nuclear power stations.

The first public meeting was extremely lively. Following the meetings each group will submit an extensive report which will be further discussed publicly between adversaries and supporters of nuclear power. No party whip will be applied in Parliament, the Chancellor has said.

If in the end a major expansion of nuclear power production were rejected, Austria would have to take drastic steps to curb the further increase in power, and energy consumption generally. Alternative sources of energy, save undesirable imports, are in the short term limited though the long term prospects for solar energy seem good. There is no doubt, however, that the scope for energy conservation in Austria is enormous: energy has been anomalously cheap, with oil prices low until 1974 and the sales price of electric power not keeping pace with inflation.

One perhaps inevitable, if regrettable, feature of the information campaign is the near-absence of a crucial issue: the subject of the plutonium economy and weapons proliferation. This problem is not so obvious to the citizens of a small and neutral country that spends little on the military; the success or otherwise of the bold venture they have embarked upon, however, will be watched closely.

\title{
REPROCESSING
}

\section{Permission to process}

Gillian Boucher reports on recent developments in plans for the reprocessing of nuclear fuel in Britain.

THE decision last week by Cumbria County Council's Planning Committee to approve in principle the $£ 600-700$ million programme for the expansion of the nuclear fuel reprocessing plant at Windscale brings Britain perceptibly closer to becoming a world reprocessing centre. Unless $\mathrm{Mr}$ Shore, the Secretary of State for the Environment, exercises his option to re-examine the question within 21 days of receiving notification of the committee decision, outline planning approval is automatic. That will remove probably the greatest single impediment to the signing of the controversial nuclear reprocessing deal with Japan.

To gain planning permission will be an important victory for the nuclear industry which, since the negotiations with Japan were publicised at the end of last year, has been fighting a noisy battle with well-organised environmental groups. Fears centre on the prospect of Britain taking on longterm storage of other countries fuels which she has reprocessed-becoming what the popular press has called the world's nuclear "dustbin"-and the dangers of sabotage if plutonium is shipped back to the country of origin.

After a five-month delay to the negotiations with Japan to allow time for public debate, Mr Anthony Wedgwood Benn, the Secretary of State for Energy, announced in March of this year that foreign deals would be acceptable if Britain did not have to store the fuels on a long-term basis but had the option of returning them to the country of origin. But the Flowers Commission said in its report on nuclear power and the environment that it would be unwise to take up the option, that it was best to avoid transporting the wastes if possible and that long-term storage in geological formations would almost certainly be safer in the UK than in seismically active Japan.

The deal originally being discussed with the Japanese utilities was for British Nuclear Fuels Ltd (BNFL), the state-owned company which operates Windscale, to reprocess 3270 tonnes of spent Japanese oxide fuel during the 1980s. The deal was worth around $£ 4000$ million Including a large down-payment. But the delay for public debate gave the French reprocessing organisation, Cogema, a chance to declare its interest; both BNFL and Cogema, a subsidiary of the French Atomic Energy Commission, are partners in United Reprocessors, an Anglo-French-German marketsharing body. The final contract, now likely to be signed in the next few weeks, will probably share the Japanese work equally between Britain and France. British contracts with other countries are also being negotiated.

BNFL has had government approval of its plans to invest $£ 245$ million on extending and improving the existing Magnox fuel reprocessing plant and $£ 40$ million on development of the vitrification process; it still awaits the crucial approval of the $£ 350$ million

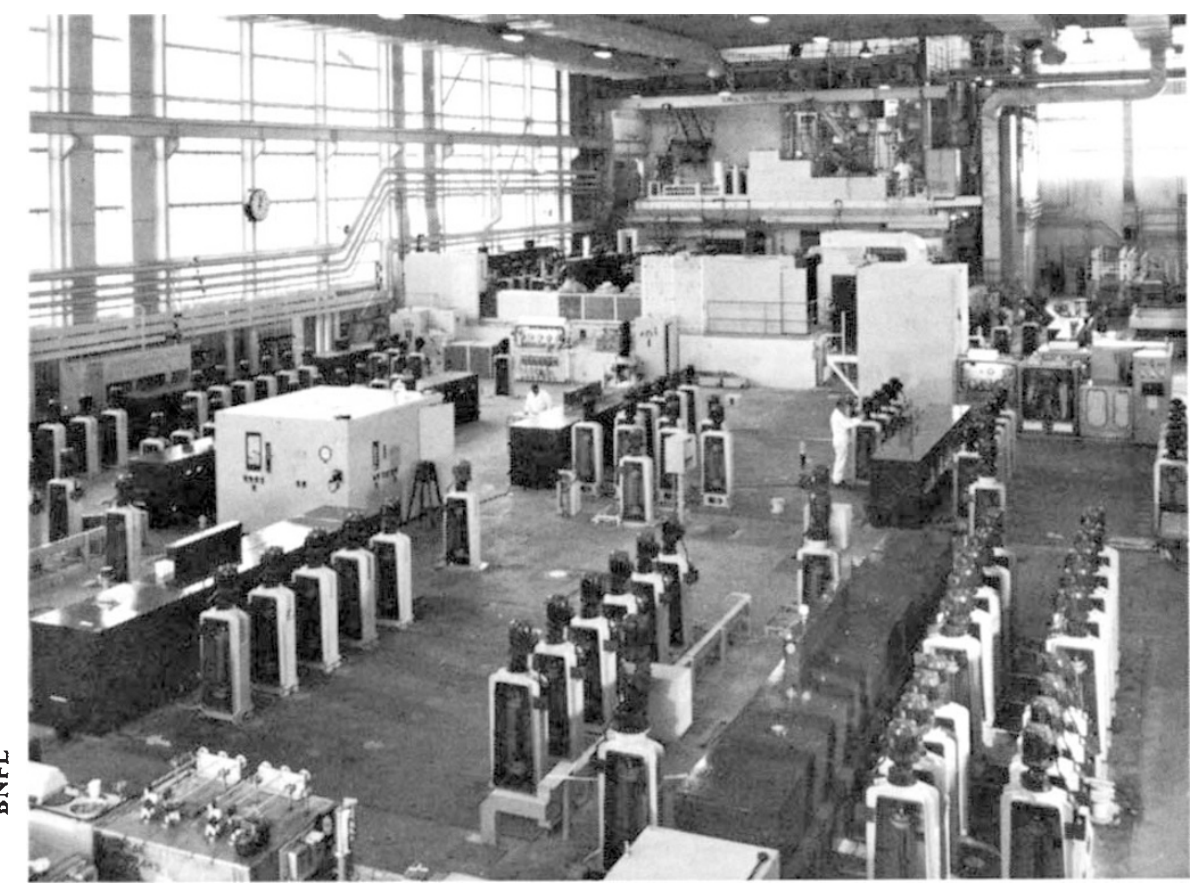

Windscale reprocessing plant 
investment on Thorp, the oxide fuel plant, which will be vital if Britain is to become a big exporter of its reprocessing services. If business prospects continue to look good, permission will almost certainly be forthcoming.

Cumbria County Council has had a daunting task in assessing the application for planning permission-weighing on the one hand 2,000 jobs in an area of high unemployment and the prospect of much-needed foreign earnings, some of which have already been lost to France through delays, against unfamiliar dangers to a rural community on the other. The Windscale workers have been staunchly in favour of expansion and wanted the County Council to make its decision without further delay. But Friends of the Earth, Half-life, the Conservation Society and the Town and Country Planning Association among others, concerned principally with the oxide plant, wanted the matter referred to a public enquiry.

In the end the committee passed a resolution saying that it was "minded to approve" the application "subject to agreement of appropriate conditions" but passed the final responsibility over to $\mathrm{Mr}$ Shore as the application was a "departure from a fundamental provision of the county development nlan". At the beginning of this week the Department of the Environment said it had still not received formal notification of the Committee's decision. The pressure groups will continue to call for a public inquiry in the little time remaining.

BNFL has been accused by the Lawyer's Ecology Group of providing

\section{Why reprocess?}

THE short answer is to make plutonium for fast breeder reactors. Though fast breeders will make us virtually independent of $U_{235}$ sources, the supplies of plutonium and depleted uranium produced by the present generation of thermal reactors are essential for them. But much depleted uranium is treated before use in thermal reactors. Reprocessing also makes environmental sense. The $30 \%$ waste left after the removal of uranium and plutonium is more compact and easily stored than the untreated spent fuel.

A reprocessing works is essentially a straightforward chemical plant with elaborations necessitated by the radioactivity of the materials. The burnt fuel (uranium metal in the case of the Magnox reactors currently in use in Britain, uranium oxide for other reactors including AGRs and PWRs) is dissolved in nitric acid and the uranium and plutonium extracted with an organic solvent. The remaining highly active acid solution containing a variety of $\alpha$ and $\beta$ emitters is at present stored in elaborate stainless steel tanks,

Incorporating the wastes in a solid would allow less hazardous storage, perhaps in deep boreholes either on land or under the sea. Solidification

the County Council with "the sketchiest ever (application) ever offered for any major development" and of leaving it "until all the options were closed". But although the replies to the County Council's detailed questions were only also makes long-distance transport feasible and, if transport of wastes back to their country of origin is made compulsory, will be the sine qua non for Britain's role as a major international processor of nuclear fuels. A process of vitrification developed at Harwell in the late 1950s and known as Harvest has been taken up by British Nuclear Fuels who hope to be constructing a demonstration plant at Windscale by 1980 . But the technological prospect is daunting, combining as it does intense radioactivity with the high temperatures needed for glass making.

Another large question mark hangs over the business of processing oxide fuel which, being more highly irradiated, poses greater problems than Magnox fuel. At present there is no commercial scale oxide fuel reprocessing plant in operation anywhere in the western world, though the La Hague plant opened earlier this year is approaching that level. At Winsdcale a "head-on" plant for preprocessing oxide fuel before it joined the Magnox fuel was in operation, but an accident in 1973 in which a number of workers were contaminated led to the closure of the plant. It is expected to reopen next year.

just ready in time for the public debate, Professor J. H. Fremlin, the County Council's independent scientific consultant, found he had all the information he needed to assess the dangers to the public at large.

\section{BRITAIN}

\section{A case of suitable treatment?}

A number of members of the World Federation of Scientific Workers received inexplicable treatment from the Home Office when they tried to enter Britain for the federation's 1/th General Assembly on September 17-23. Professor Eric Burhop of University College London, who is President of the federation, gave Nature his view of what happened

THE Federation's General Assembly, its highest policy-determining body, meets every three years. This year, on the occasion of its 30th anniversary and amidst some difficulty for many participants, the assembly was held in London, where the organisation was founded. Professor Burhop tells his story with the aim of preventing another recurrence in the future-the assembly had once experienced even more serious difficulties some 15 years ago.

Before the latest meeting, says Burhop, a British MP associated with the affiliated organisation ASTMS explained to the then Home Secretary, $\mathrm{Mr}$ Roy Jenkins, the nature of the planned meeting and the countries from which the attending scientists would come. That was in February. $\mathrm{Mr}$ Jenkins' reply, according to Burhop, stated that he could see no reason why the assembly should not meet in London; but he added that people coming from countries from which visas were required should make their application in good time and certainly not less than two weeks before they wished to enter Britain, to give time for the necessary processing. "We informed our affiliated organisations accordingly," says Burhop, "and expected there would be no more trouble. It was not until September 14, three days before the Assembly was due to commence, that we began to receive cables from delegates from distant parts that their visas had not been issued."

Burhop is quick to repudiate the frequent charge that the federation is a communist-controlled or Sovietdominated organisation. That is not true, he says, and never has been. $\mathrm{He}$ summarises the aims of the federation as international scientific cooperation, the protection of the freedom and rights of scientific workers, the constructive application of science and international agreement on disarmament and the eventual abolition of nuclear weapons. He describes the attempts of the federation after the Second World War to hold meetings in London to discuss nuclear weapons as "sufficient to send sections of our 